Article

\title{
Casticin Inhibits A375.S2 Human Melanoma Cell Migration/Invasion through Downregulating NF- $k B$ and Matrix Metalloproteinase-2 and -1
}

\author{
Zih-Yun Wu ${ }^{1}$, Jin-Cherng Lien ${ }^{2}$, Yi-Ping Huang ${ }^{3}$, Ching-Lung Liao ${ }^{4}$, Jen-Jyh Lin ${ }^{5}$, \\ Ming-Jen Fan ${ }^{6}$, Yang-Ching Ko ${ }^{7}$, Yu-Ping Hsiao ${ }^{8}$, Hsu-Feng Lu ${ }^{9,10, *,+}$ and \\ Jing-Gung Chung ${ }^{1,6, *,+}$ \\ 1 Department of Biological Science and Technology, China Medical University, No. 91, Hsueh-Shih Road \\ Taichung 40402, Taiwan; mary28862001@gmail.com \\ 2 School of Pharmacy, China Medical University, Taichung 40402, Taiwan; jclien@mail.cmu.edu.tw \\ 3 Department of Physiology, China Medical University, Taichung 40402, Taiwan; yphuang@mail.cmu.edu.tw \\ 4 School of Chinese Medicine, China Medical University, Taichung 40402, Taiwan; qbking@ms29.hinet.net \\ 5 Division of Cardiology, China Medical University Hospital, Taichung 40402, Taiwan; pig222@ms15.hinet.net \\ 6 Department of Biotechnology, Asia University, Taichung 40402, Taiwan; mjfan@asia.edu.tw \\ 7 Institute of Clinical Medical Science, China Medical University, Taichung 40402, Taiwan; \\ kyc621006@yahoo.com.tw \\ 8 Department of Dermatology, Chung Shan Medical University Hospital, Taichung 40402, Taiwan; \\ cs1601@csmu.edu.tw \\ 9 Department of Restaurant, Hotel and Institutional Management, Fu-Jen Catholic University, \\ New Taipei 112, Taiwan \\ 10 Departments of Clinical Pathology, Cheng Hsin General Hospital, No. 45, Cheng Hsin St., Taipei 112, Taiwan \\ * Correspondence: ch1835@chgh.org.tw (H.-F.L.); jgchung@mail.cmu.edu.tw (J.-G.C.); \\ Tel.: +886-2-2826-4400 (ext 5850) (H.-F.L.); +886-4-2205-3366 (ext 8000) (J.-G.C.); \\ Fax: +886-2-2826-4517 (H.-F.L.); +886-4-2205-3764 (J.-G.C.) \\ + These authors contributed equally to this work.
}

Academic Editor: Derek J. McPhee

Received: 25 February 2016; Accepted: 16 March 2016; Published: 19 March 2016

\begin{abstract}
Casticin is one of the main components from Fructus Viticis, which is widely used as an anti-inflammatory agent. The mechanism of how casticin affects melanoma cell migration and invasion is still not well known. Here we studied the anti-metastasis effects of casticin on A375.S2 melanoma cells by using a non-lethal concentration. First; we used an adhesion assay to test the A375.S2 cells' adhesion ability after treatment with casticin. We next investigated the cell migration ability after casticin treatment by using a wound healing assay to prove that the migration of A375.S2 cells can be inhibited by casticin and double checked the results using the transwell-migration assay. The suppressive effects on matrix metalloproteinase-2; and -9 (MMP-2; and -9) activities were examined by gelatin zymography. Furthermore, western blotting was used to investigate the protein level changes in A375.S2 cells. We found that p-EGFR; Ras and p-ERK1/2 are decreased by casticin, indicating that casticin can down-regulate the migration and invasion ability of A375.S2 cells via the p-EGFR/Ras/p-ERK pathway. The NF- $\mathrm{KB}$ p65 and p-ERK levels in nuclear proteins are also decreased by treatment with casticin. An EMSA assay also discovered that the NF- $\mathrm{kB}$ p65 and DNA interaction is decreased. NF- $\mathrm{kB}$ p65 protein level was examined by immunofluorescence staining and also decreased. Our findings suggest that casticin has anti-metastatic potential by decreasing the invasiveness of A375.S2 cells. We also found that casticin suppressed A375.S2 cell proliferation and cell adhesion ability, but did not affect cell death, as examined using cytometry and a collagen adhesion assay. Based on these observations, casticin could be used as an inhibitor of migration and invasion of human melanoma cells in the future.
\end{abstract}

Keywords: casticin; MMP-2; migration; invasion; A375.S2 cells 


\section{Introduction}

Cancer metastasis accounts for more than $90 \%$ of all cancer-related deaths and it has been reported to be a multistep process including cell adhesion, migration and invasion [1-3]. Inhibiting cancer cell metastasis is one of the strategies for the cancer therapy and research [4]. Tumor invasion and migration is an indispensable process for cancer metastasis, and requires proteolytic degradation of the extracellular matrix (ECM) and basement membrane of normal surrounding tissues by a family of zinc-dependent proteolytic enzymes named matrix metalloproteinases (MMPs) [5,6]. It was reported that MMP expression is increased in a variety of cancer types, where it is indicative of invasive disease and leads to difficult clinical prognosis [7]. MMPs were reported to involve cell motility and adhesion [8] and metastasis [9]. Among MMPs, MMP-2 and MMP-9 in particular, have been recognized to play critical roles in the degradation of ECM proteins in the basement membrane [10,11]. It was also reported that high levels of MMP-2 and MMP-9 expression are associated with inflammation, tissue repair, cancer progression, invasion, and metastasis [12]. Therefore, the suppression of MMPs, including MMP-2/9, and decreasing cancer cell invasion and migration are one of the strategies for preventing cancer cell metastasis.

Traditional Chinese Medicine has used the fruit of Vitex rotundifolia L. which grows in the countrysides of China, Taiwan, and Korea [13], for treating gastroenteritis, inflammation, and headaches [14,15]. Many investigators are interested in investigating the components of medicinal herbs used in complementary and alternative medicines [16]. Casticin, vitexilactone, viteagnusin I, and several vitetrifolins (D-G) have been isolated from Vitex rotundifolia [17] and it was reported that casticin (a polymethoxyflavone) exerts multiple biological and pharmacological activities [18,19]. Casticin is one of the active ingredients derived from Fructus Viticis [20] and it inhibited acute inflammation in a mouse model [21], induced cervical cancer cell apoptosis through reactive oxygen species-mediated mitochondrial signaling pathways [22], induced cytocidal effects against the human promyelocytic cell line HL-60 [23], induced gastric cancer cell apoptosis through endoplasmic reticulum stress [24] and suppressed self-renewal and invasion of lung cancer stem-like cells from A549 cells through down-regulation of pAKT [25]. Casticin was also one of the ingredients from Vitex agnuscastus which have been shown to exhibit a potent lipoxygenase inhibition [26] and also inhibited monocyte oxidative burst [27]. Casticin was isolated from Vitex negundo and shown to inhibit cell cycle progression at G2/M phase and induce apoptosis in mammalian cancer cells [28].

Recently, it was reported that casticin inhibits COX-2 and iNOS expression via suppression of NF- $\kappa B$ and MAPK signaling in lipopolysaccharide-stimulated mouse macrophages [29]. Casticin may thus have therapeutic potential in inflammatory lung diseases, such as chronic obstructive pulmonary disease (COPD) [30]. Casticin suppressed migration of eosinophil and expression of chemokines and adhesion molecules in A549 lung epithelial cells via NF- KB inactivation [31]. Although casticin has been reported to exert anti-oxidant, anti-inflammatory, and anticancer activities, there is no available information to show casticin inhibits cancer cell migration and invasion in human melanoma A375.S2 cells in vitro. Herein, we show the first evidence of the anti-migration and-invasion activity of casticin on A375.S2 cells. This study demonstrates that casticin is a potent anti-metastasis agent against human melanoma cells through the signaling mechanisms of the NF-KB and MAPK pathways in A375.S2 cells.

\section{Results}

\subsection{Casticin Decreased the Cell Viability of A375.S2 Cells}

In order to investigate the cytotoxicity of casticin on A375.S2 cells, we treated them with casticin $(0,100,125,150,175$ and $200 \mathrm{nM})$ for $24 \mathrm{~h}$ before the cells were collected for viability assay and the results are shown in Figure 1. The data indicated a significant decrease in the number of living cells and about 7\%-9\% reduction in A375.S2 cells treated with 150-200 nM casticin when compared to control groups. However, 100-125 nM of casticin did not significantly reduce the total viable cells 
of A375.S2. Based on these findings, we have used casticin at concentrations of $100-200 \mathrm{nM}$ in all subsequent experiments.

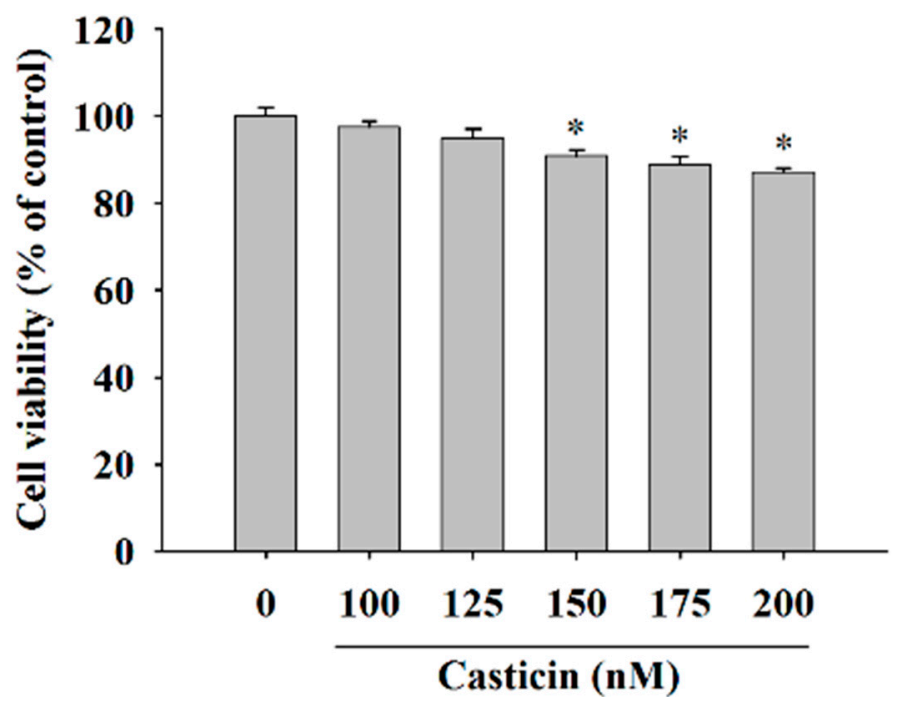

Figure 1. Casticin affects the percentage of viable A375.S2 cells. Cells $\left(5 \times 10^{4}\right.$ cells/well) were incubated with $0,100,125,150,175$ and $200 \mathrm{nM}$ for $24 \mathrm{~h}$ before cells were harvested and the percentage of viable cells were determined by flow cytometry as described in the Materials and Methods Section. ${ }^{*} p<0.05$, significant difference between casticin-treated groups and the control as analyzed by Student's $t$ test.

\subsection{Casticin Inhibits the Motility of A375.S2 Cells}

In order to investigate whether casticin inhibits A375.S2 cell mobility, a wound healing (cell migration) assay was performed and results are shown in Figure 2, where continuous rapid movement of A375.S2 cells in a scratch wound assay was found in the control group. However, with 100, 150 and $200 \mathrm{nM}$ casticin treatment, the migration of A375.S2 cells was significantly reduced in a concentration-dependent manner (Figure 2B).

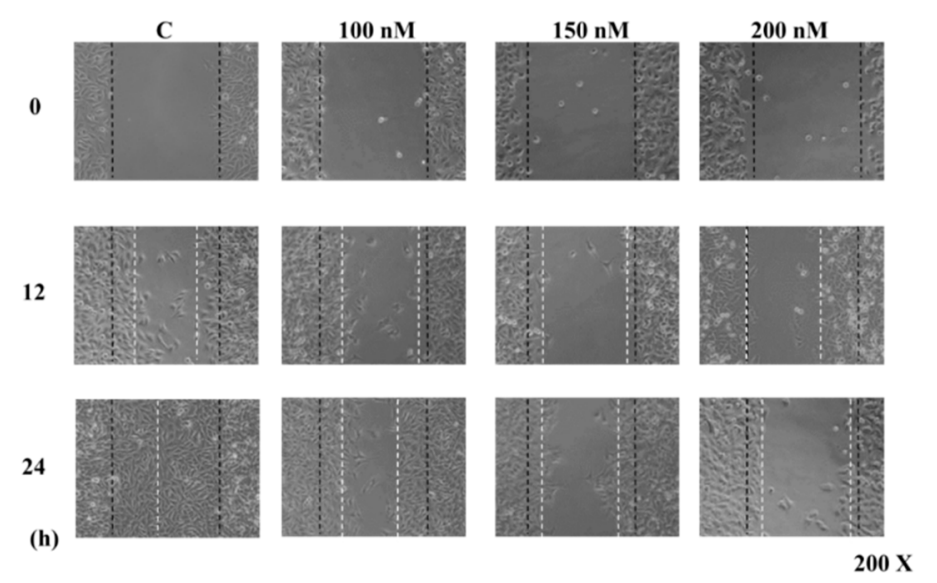

(A)

Figure 2. Cont. 


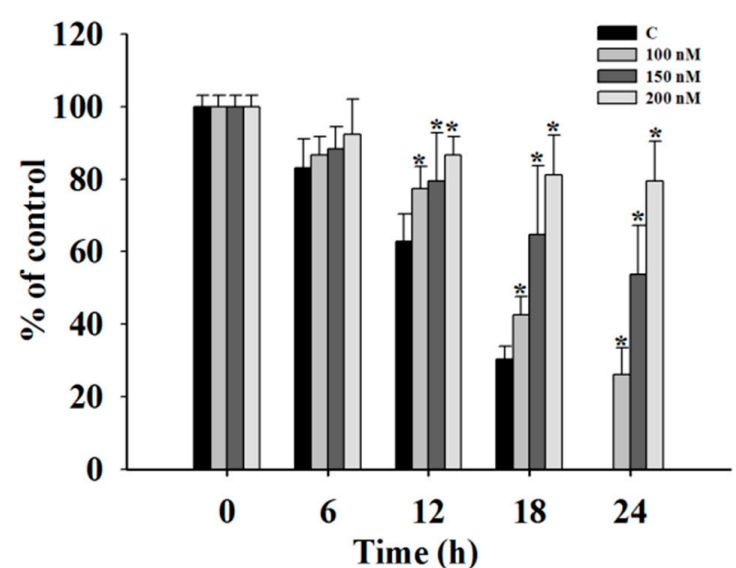

(B)

Figure 2. Casticin inhibits the mobility of A375.S2 cells. Cells $\left(2.5 \times 10^{5}\right.$ cells / well $)$ were placed into a 6-well plate for confluent monolayer formation in complete medium. Cells in monolayers were wounded by a sterile P200 micropipette tip and remaining cell monolayers were incubated in the medium containing $0,100,150$ and $200 \mathrm{nM}$ of casticin for $24 \mathrm{~h}$. At the indicated time $(0,6,12,18$ and $24 \mathrm{~h}$ ) after scraping, the wound areas were photographed (A) and the percentage of cell migration inhibition (B) were calculated as described in the Materials and Methods Section. ${ }^{*} p<0.05$, significant difference between casticin-treated groups and the control as analyzed by Student's $t$ test.

\subsection{Casticin Inhibit Adhesion of A375.S2 Cells}

Cancer cell adhesion had been recognized to be a crucial step during cancer invasiveness. Thus, we investigated the effect of casticin on cell adhesion and the results are shown in Figure 3. The data demonstrated that pre-treatment of A375.S2 cells with casticin for $24 \mathrm{~h}$ significantly inhibited cell adhesion. Fewer casticin-treated cells adhered to fibronectin than casticin-untreated cells and these effects are dose-dependent, which indicates that the adhesion ability of A375.S2 cells was inhibited by casticin treatment.

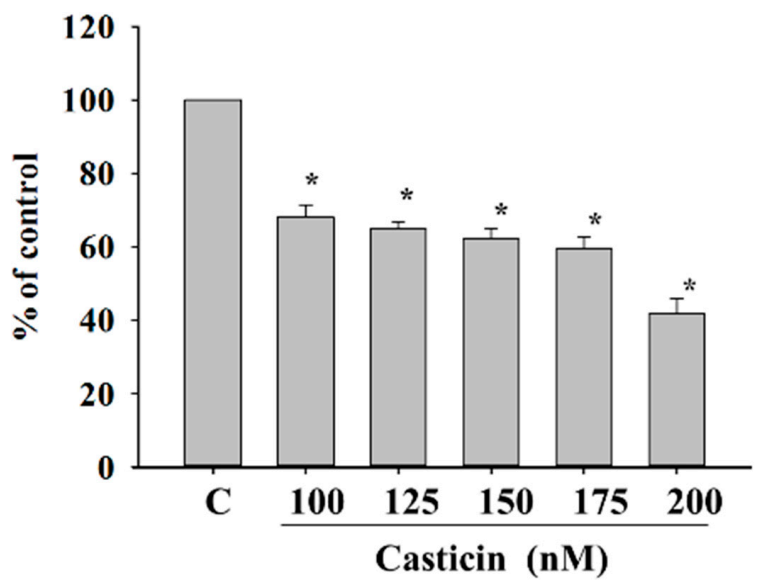

Figure 3. Casticin inhibits the adhesion of A375.S2 cells. Cells $\left(5 \times 10^{4}\right.$ cells/well $)$ plated in 12 -well plate were incubated with casticin $(0,100,125,150,175$ and $200 \mathrm{nM})$ for $24 \mathrm{~h}$, unattached cells were removed, and attached cells were mixed in $4 \%$ paraformaldehyde and were stained with $0.02 \%$ crystal violet solution for $10 \mathrm{~min}$ at room temperature. Then DMSO was used to dissolve crystal violet, and O.D. was measured at $570 \mathrm{~nm}$ by using microplate reader as described in the Materials and Methods section. Percentage of adhesion was calculated based on the adhesion cells compared to the control. ${ }^{*} p<0.05$, significant difference between casticin-treated groups and the control as analyzed by Student's $t$ test. 


\subsection{Casticin Inhibited the Cell Migration and Invasion of A375.S2 Cells}

Cell migration and invasion are involved and play important steps in cancer metastasis. Therefore, the inhibitory effects of casticin on A375.S2 cell migration and invasion were measured by a Transwell cell migration and invasion assays and the results are shown in Figure 4. Treatment of A375.S2 cells with increasing concentrations of casticin led to a dosage-dependent decrease in cell vertical migration through the Transwell chamber (Figure 4A,B). Casticin significantly inhibited in vitro cell migration by $40 \%$ and $93 \%$ for 100 and $200 \mathrm{nM}$ at $24 \mathrm{~h}$ compared to control cells (Figure $4 \mathrm{~A}, \mathrm{~B}$ ). We obtained similar results in a wound healing assay where casticin inhibited the in vitro mobility of A375.S2 cells (Figure 3). Cell invasion was measured by Transwell matrigel invasion assay and results shown in Figure 4C,D. That indicated that the invasive ability of A375.S2 cells was reduced by casticin treatment and these effects are ocurr a dose-dependent manner (Figure 4C,D). Casticin significantly inhibited in vitro cell invasion by $56 \%$ and $88 \%$ for 100 and $200 \mathrm{nM}$ at $24 \mathrm{~h}$ compared to control cells (Figure 4D).

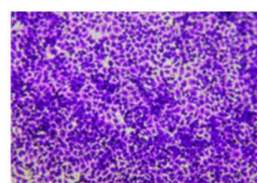

C

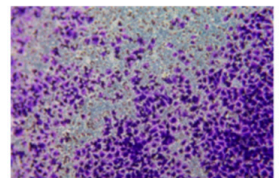

$150 \mathrm{nM}$

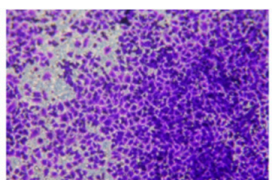

$100 \mathrm{nM}$

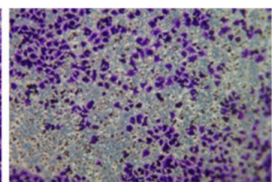

$175 \mathrm{nM}$

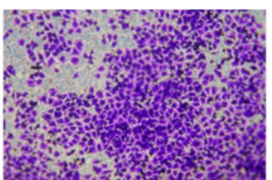

$125 \mathrm{nM}$

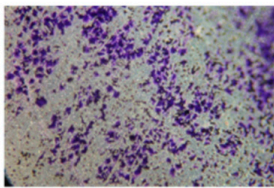

$200 \mathrm{nM}$

(A)

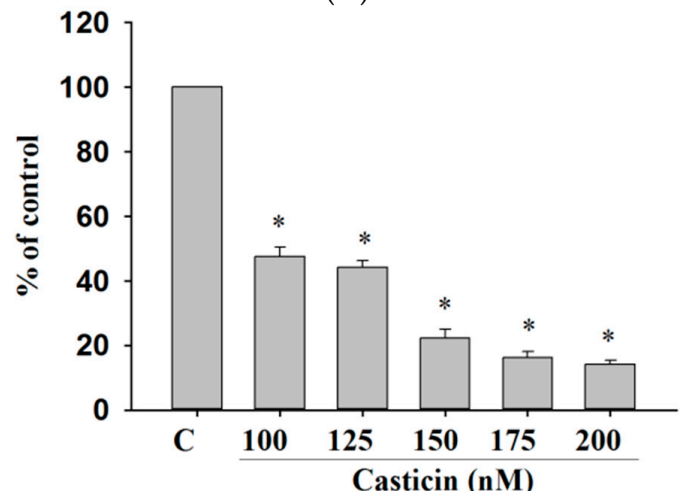

(B)

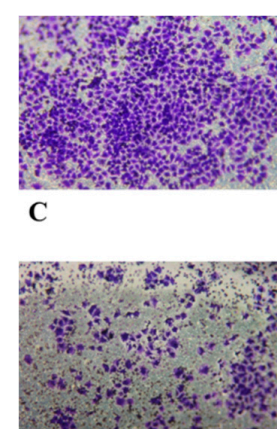

$150 \mathrm{nM}$

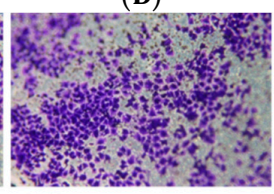

$100 \mathrm{nM}$

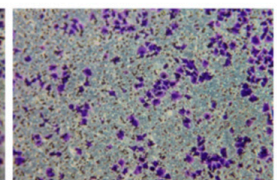

$175 \mathrm{nM}$

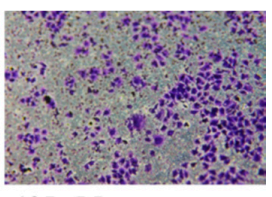

$125 \mathrm{nM}$

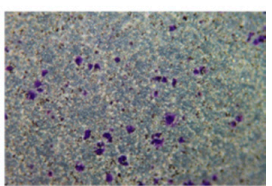

$200 \mathrm{nM}$

(C)

Figure 4. Cont. 


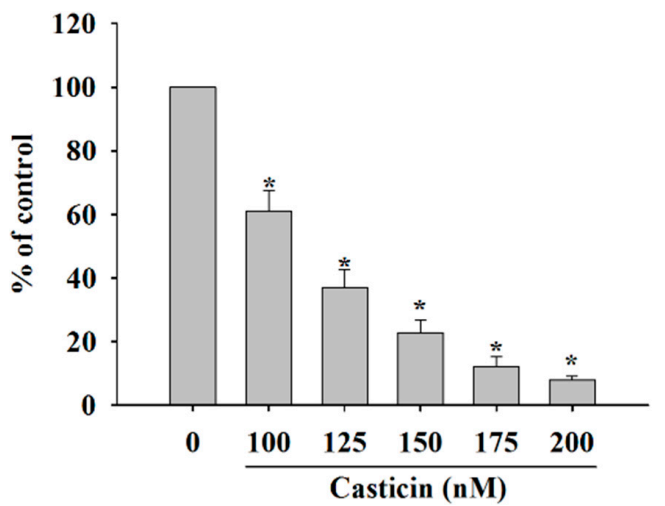

(D)

Figure 4. Casticin suppressed the migration and invasion of A375.S2 cells in vitro. Cells $\left(2 \times 10^{4}\right.$ cells /well $)$ were placed on filters which were coated with collagen and incubated with casticin $(0,100,125,150,175$ and $200 \mathrm{nM})$ for $24 \mathrm{~h}$. Cells penetrated through to the lower surface of the filter which were stained with crystal violet and were photographed under a light microscope at $\times 100$ (A) and the cells were counted (B); Cells $\left(2 \times 10^{4}\right.$ cells/well) that penetrated through with the matrigel to the lower surface of the filter were stained with crystal violet and were photographed under a light microscope at $\times 100$ (C) and cells were counted (D). Results were obtained from three independent experiments. ${ }^{*} p<0.05$, significant difference between casticin-treated groups and the control as analyzed by Student's $t$ test.

\subsection{Casticin Downregulates the Proteolytic Activity and Protein Expression of MMP-2}

Gelatin zymography and western blotting assay were employed to assess the effects of casticin on the activity of secreted MMP-2 and protein expression, respectively, and the results are shown in Figure 5. Figure 5A indicates the appearance and intensity of clear bands which reflect the fact that the proteolytic activity of MMP-2 was reduced upon exposure to casticin in a dose-dependent manner. At $200 \mathrm{nM}$ of casticin, the activity of MMP-2 was reduced by $50 \%$ as compared to the untreated control (Figure 5A). Furthermore, the western blotting results indicated that casticin inhibited the protein expression of MMP-2 in a dose-dependent manner (Figure 5B) and at $200 \mathrm{nM}$ of casticin the protein expression of MMP-2 was reduced by $60 \%$ as compared to the untreated control (Figure 5B).

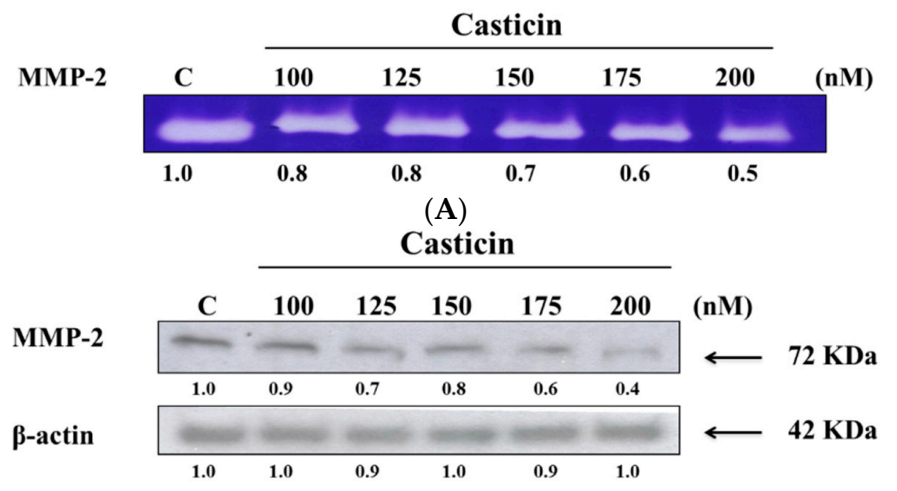

(B)

Figure 5. Casticin inhibited the enzyme activities and protein expression of MMP-2 in A375.S2 cells. Cells $\left(2.5 \times 10^{5}\right.$ cells/well) were plated in 6-well tissue culture plates and treated with different concentrations of casticin $(0,100,125,150,175$ and $200 \mathrm{nM})$. The culture medium from treated cells was collected and $50 \mu \mathrm{g}$ of medium were separated on $8 \%$ sodium dodecyl sulfate (SDS)-polyacrylamide gel polymerized with $0.19 \%$ gelatin as described in the Materials and Methods section. MMP-2 activity was visualized as clear bands against the blue-stained gelatin background (A); MMP-2 protein was quantitated and assayed by Western blotting (B) as described in the Materials and Methods section. 


\subsection{Casticin Inhibits the Binding and Protein Expression of $N F-\kappa B$}

After A375.S2 cells were treated with $200 \mathrm{nM}$ casticin for 0, 6, 9 and $12 \mathrm{~h}$, cells were then harvested for examining the binding of NF- $\mathrm{BB}$ p 65 promoter and protein expression of NF- $\mathrm{B}$ p 65 which were assayed by EMSA and western blotting, respectively, and the results are shown in Figure 6 . The results

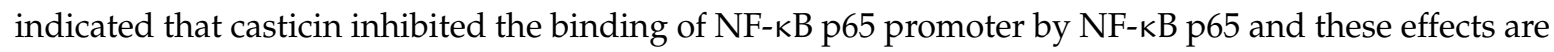
time-dependent (Figure 6A). Furthermore, the protein expression of NF- $\kappa$ B p65 in nuclear fraction was inhibited by casticin in a time-dependent manner (Figure 6B).

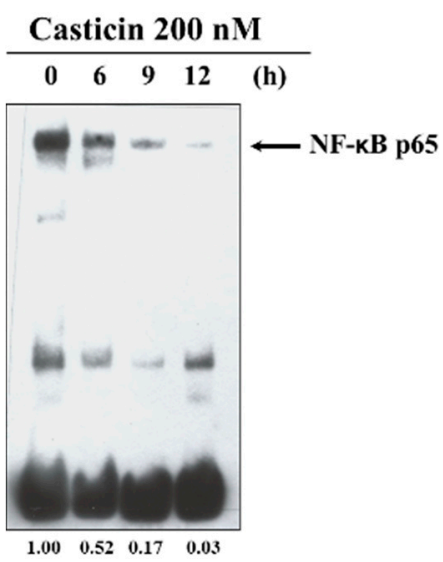

(A)

Casticin $200 \mathrm{nM}$

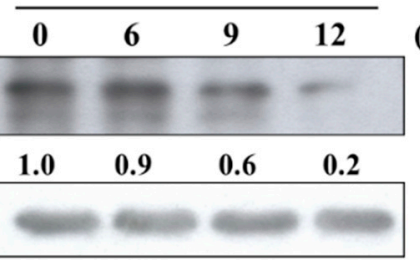

(h)

$65 \mathrm{KDa}$

29 KDa

(B)

Figure 6. Casticin inhibited the NF- $\mathrm{KB}$ p65 binding on the promoted of NF- $\mathrm{kB}$ p65 and also inhibited NF-KB p65 protein expression in A375.S2 cells. $1 \times 10^{6}$ cells in $10 \mathrm{~cm}$ dish were treated with $200 \mathrm{nM}$ casticin for 0, 6, 9 and $12 \mathrm{~h}$. Nuclear extracts were prepared using the NE-PER Nuclear and Cytoplasmic Extraction kit and quantitated protein concentrations and 5'-biotin-GATCCAGGGGACTTTCCCTAGC-3' corresponding to the consensus site of NF-кB p65 was used as biotin end-labeled oligonucleotide sequences. EMSA was used for measuring NF- $\mathrm{kB}$ p65 binding on the promoter of NF- $\mathrm{BB}$ p65 (A) as described in the Materials and Methods section, or protein was used to do western blotting for measuring protein expression of nuclear NF- $\mathrm{B}$ p65 (B).

\subsection{Casticin Alters the Levels of Proteins Associated with Migration and Invasion of A375.S2 Cells}

We have shown that casticin inhibited the cell migration and invasion of A375.S2 cells, thus, we further investigated whether casticin inhibited cell migration and invasion through the suppression of proteins which are associated with cell migration and invasion. The results from western blotting are shown in Figure 7. 


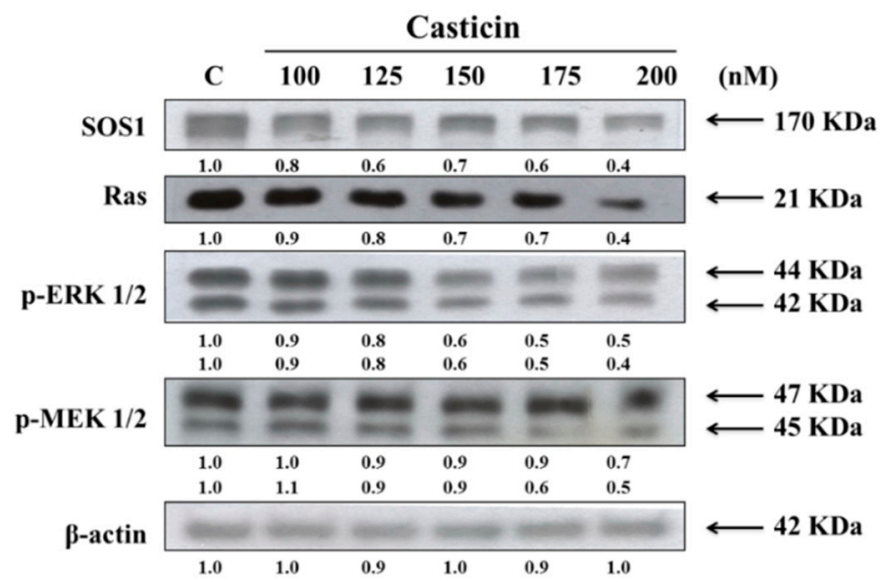

(A)

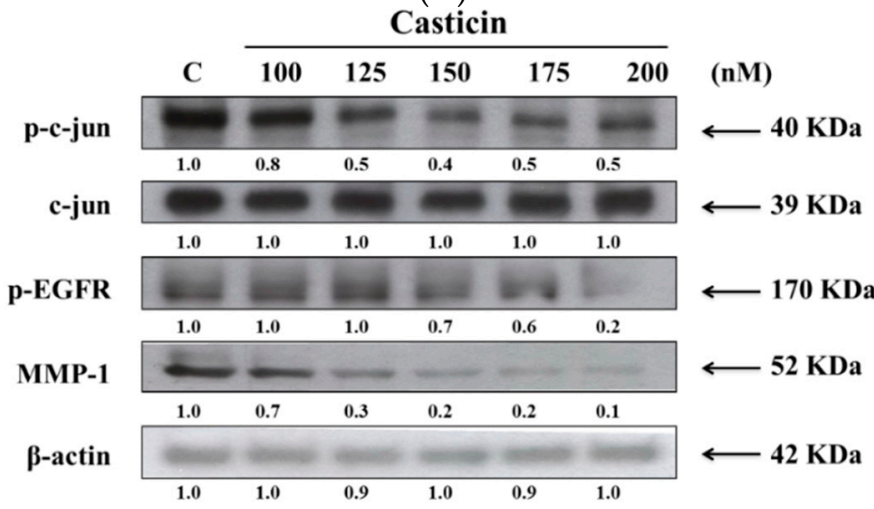

(B)

Figure 7. Casticin affect the levels of associated proteins in migration and invasion of A375.S2 cells. Samples were obtained from nuclear extract preparation or A375.S2 cells $\left(1 \times 10^{6}\right.$ cells $/$ dish $)$ were kept in $10 \mathrm{~cm}$ dish and were treated with $0,100,125,150,175$ and $200 \mathrm{nM}$ of casticin for $24 \mathrm{~h}$. Each total cell lysate was prepared for western blotting assay as described in the Materials and Methods Section and after blocking with $5 \%$ nonfat skim milk, the membrane was probed with primary antibodies for SOS1, Ras, p-ERK 1/2and p-MEK 1/2 (A), p-c-jun, c-jun, p-EGFR and MMP-1 (B).

As indicated in Figure 7, casticin treatment resulted in a reduction of SOS1, Ras, p-ERK $1 / 2$ and p-MEK 1/2 (Figure 7A), p-c-jun, p-EGFR and MMP-1 (Figure 7B) but did not affect c-jun in A375.S2 cells. These results showed that the inhibition of those associated with migration and invasion proteins expressions may be involved in reduced expression of MMP-2 and reduced A375.S2 cell migration and invasion.

\section{Discussion}

It is well known that cancer metastasis is a complex process involving cell migration, adhesion and invasiveness [32]. Cancer invasion depends on the action of extracellularly secreted proteases such as MMPs to degrade the basement membrane barrier and to assist cancer cells to escape and migrate. The inhibition of MMPs secretion in cancer cells may be an effective strategy for preventing cancer cell migration and invasion. Melanomas are types of skin tumors that generally have a poor cure rate because of their invasive behavior. The treatments for melanoma include surgery, radiotherapy, and chemotherapy. In the present study, we investigated the role of casticin (a naturally occurring plant phytochemical) in suppressing cell growth, migration, adhesion and invasion of human melanoma A375.S2 cells in vitro. Several previous studies have reported that casticin displayed cytotoxic effects on many human cancer cell lines through different molecular pathways, including caspase-dependent 
and mitochondria-dependent pathways $[22,23,28]$, whereas there is no available information on the effects of casticin on the inhibition of cancer cell migration and invasion of human melanoma cells.

Our results showed that casticin exhibited dose-dependent toxicity towards A375.S2 cells. This observation is in agreement with the cytotoxic property of casticin reported in other findings [21-24]. Nonetheless, little is known about the anti-metastatic potential of casticin. Hence, the migration and invasion potential of A375.S2 cells were measured with treatments of casticin at subtoxic concentrations (100-200 nM). We demonstrated for the first time that casticin, at subtoxic concentrations, could inhibit the metastasis of A375.S2 cells in a dose-dependent manner (Figure 2). Casticin inhibited cell migration by $40 \%$ and $93 \%$ for 100 and $200 \mathrm{nM}$ at $24 \mathrm{~h}$ compared to control cells (Figure 4). Casticin inhibited cell invasion by $56 \%$ and $88 \%$ for 100 and $200 \mathrm{nM}$ at $24 \mathrm{~h}$ compared to control cells (Figure 4C,D).

Thus far, the detailed mechanism by which casticin exerts inhibitory effects against the migration and invasion of A375.S2 cells is still unclear. High MMP expression has been shown to correlate with the invasive and aggressive behavior of tumors. These MMPs are secreted from cancer cells to degrade the ECM proteins in the basement membrane barrier which eventually promotes the migration and invasion behavior of the cancer cells [11,33]. MMP-2 and -9 are the gelatin enzymes which have been reported to degrade the matrix collagen and basement membrane [34,35]. It was reported that multiple signaling pathways are associated with the regulation and expression of MMPs, including the MAPK and NF-KB signaling pathways [36,37]. If agents can block one of the pathways, it may lead to inhibition of cancer metastasis.

In the present study, we demonstrated that MMP-2 activity in conditioned serum-free medium of A375.S2 cells was significantly downregulated by casticin (Figure 5). At $200 \mathrm{nM}$ of casticin, the activity of MMP-2 was reduced by $50 \%$ as compared to the untreated controls (Figure 5). This observation may indicate that the inhibition of cell invasion and migration by casticin could be mediated by the reduction in the proteolytic action of MMP-2. The results from western blotting experiments also showed that casticin reduced the protein expression of MMP-2 (Figure 5B) and MMP-1 (Figure 7B) in A375.S2 cells. In the degradation of the basement membrane, MMPs, especially the gelatinolytic MMP-2, is one of enzymes which plays a central role [38]. It was also reported that oxidative stress can drive RPE cells to strongly express MMP-1. MAPKs activation also involved the critical increased of expression of MMP-1 in EGF-induced glioma invasion [39]. Results from western blotting (Figure 7A,B) indicated that casticin suppressed the expression of p-ERK 1/2, p-MEK 1/2, p-c-jun and p-EGFR in A375.S2 cells. Thus, we suggest casticin inhibited cell migration and invasion of A375.S2 cells through the inhibition of MMP-2 and -1.

Active NF-KB signaling pathways are usually found in highly invasive cancer cells [40] and blocking NF- $\mathrm{kB}$ signaling pathways can result in decreased breast cancer cell migration [41]. NF- $\mathrm{kB}$ had been shown to play a role in the immuno-inflammatory response, especially in numerous skin diseases and skin cancer and it consists of dimeric p65 and p50 transcription factors [42]. NF- $\mathrm{kB}$ plays a role in initiation, development and promotion of skin carcinomas [42]. Herein, we found that casticin significantly inhibited the binding of NF- $\mathrm{kB}$ p 65 on NF- $\mathrm{kB}$ p 65 promoter which was assayed by EMSA (Figure 6A) and it also decreased the protein levels of NF- $\mathrm{kB}$ p65 which was measured by western blotting (Figure 6B). Furthermore, the results from Figure 7 also show that casticin decreased the expression of p-ERK 1/2, p-MEK 1/2, p-c-jun, p-EGFR and MMP-1 in A375.S2 cells, indicating that casticin inhibited cell migration and invasion and this involved NF- $\mathrm{kB}$ p65, p-EGFR and p-ERK 1/2 in A375.S2 cells in vitro.

\section{Materials and Methods}

\subsection{Chemicals and Reagents}

The natural compound casticin, dimethyl sulfoxide (DMSO) and propidium iodide (PI) were purchased from Sigma-Aldrich Corp. (St. Louis, MO, USA). Casticin formed yellow crystals, and has a 
molecular weight of 374.34 with a purity of $99.0 \%$. Casticin was dissolved in $0.1 \%$ DMSO and then diluted with phosphate-buffered saline (PBS). Cell culture materials such as MEM medium, fetal bovine serum (FBS), L-glutamine and penicillin-streptomycin were purchased from GIBCO ${ }^{\circledR} /$ Invitrogen Life Technologies (Carlsbad, CA, USA). Primary antibodies against MMP-1 and -2, NF-kB p65, SOS1, Ras, p-ERK 1/2, p-MEK 1/2, p-c-jun, c-jun and p-EGFR and secondary antibodies were obtained from Cell Signaling Technology, Inc. (Beverly, MA, USA). The enhanced chemiluminescence (ECL) detection system was obtained from Amersham Life Sciences, Inc. (Arlington Heights, IL, USA).

\subsection{Cell Culture}

Human melanoma A375.S2 cell line was obtained from the Food Industry Research and Development Institute (Hsinchu, Taiwan). Cells were cultured in MEM supplemented with 10\% fetal bovine serum (FBS), $2 \mathrm{mM}$ L-glutamine and antibiotics (100 units $/ \mathrm{mL}$ penicillin, $100 \mu \mathrm{g} / \mathrm{mL}$ streptomycin) at $37^{\circ} \mathrm{C}$ incubator with a humidified atmosphere of $95 \%$ air and $5 \% \mathrm{CO}_{2}$ [43].

\subsection{Cell's Viability Assays}

A375.S2 cells $\left(5 \times 10^{4}\right.$ cells) were plated in a 12-well plate for $24 \mathrm{~h}$ and after the required confluence was reached, cells were incubated with various concentrations of casticin $(0,100,125,150,175$ and $200 \mathrm{nM}$ ) or $0.5 \%$ DMSO as a vehicle for $24 \mathrm{~h}$. Cells were harvested from each treatment, counted and stained with PI $(5 \mu \mathrm{g} / \mathrm{mL})$ and then were immediately analyzed by using flow cytometer (BD Biosciences, Bedford, MA, USA) assay for the percentages of viability as previously described [10].

\subsection{Wound Healing Mobility Assay}

To determine the effect of casticin on migration of A375.S2 cells in vitro, cells were seeded at $2.5 \times 10^{5}$ cells/well in 6-well plate and grown to about $90 \%$ confluence after $24 \mathrm{~h}$. Medium was removed and cell monolayers were wounded by manually scraping the cells by a sterile P200 micropipette tip. Debris was washed off with PBS three times and cells were then cultured in serum-free medium containing $0,100,150$ and $200 \mathrm{nM}$ of casticin for $24 \mathrm{~h}$ at $37^{\circ} \mathrm{C}$ and the wound areas were photographed [10].

\subsection{Adhesion Assay}

A375.S2 cells $\left(5 \times 10^{4}\right.$ cells/well) were plated in 12-well plate for $12 \mathrm{~h}$ and then were incubated with casticin $(0,100,125,150,175$ and $200 \mathrm{nM})$ for $24 \mathrm{~h}$. Cells were harvested from each treatment, and reseed in the 24-well for $3 \mathrm{~h}$. Rinse cells three times with PBS and then fixed cells with $4 \%$ paraformaldehyde at room temperature for $15 \mathrm{~min}$. Add $0.02 \%$ crystal violet solution to stain cells for $10 \mathrm{~min}$ at room temperature, and then added DMSO to dissolve crystal violet. The O.D. was measured at $570 \mathrm{~nm}$ by using microplate reader (Bio-Rad Laboratories, Hercules, CA, USA). Percentage of adhesion was calculated based on the adhesion cells compared to the control [44].

\subsection{Cell Migration and Invasion Assay}

For cell migration and invasion assays, A375.S2 cells $\left(2 \times 10^{4}\right.$ cells/well $)$ were placed in Transwell cell culture chambers ( $8 \mathrm{~mm}$ pore size; Merck Millipore Corp., Billerica, MA, USA), which were coated with collagen for migration assay or matrigel for invasion assay for $24 \mathrm{~h}$. Cell suspension was placed in the upper chamber of the Transwell insert and incubated with $0.5 \%$ DMSO as control or casticin $(0,100,125,150,175$ and $200 \mathrm{nM})$, and lower chamber was filled with complete medium (90\% MEM medium containing 10\% FBS) as a chemoattractant. Cells were incubated for $24 \mathrm{~h}$ and this led cells to migrate or invasive. Migrated or invasive cells in membrane were fixed with $4 \%$ formaldehyde and then were stained with $0.02 \%$ crystal violet as described previously [44]. Cells were examined, photographed and quantified under a light microscope at $100 \times$ in five random fields per membrane. Each sample was assayed in triplicate as described previously [44]. 


\subsection{Gelatin Zymography Assay}

The enzyme activities of MMP-2 were analyzed by gelatin zymography assay. A375.S2 cells $\left(2.5 \times 10^{5}\right.$ cells $/$ well $)$ were plated in 6-well plates and then culture medium was replaced by serum-free MEM medium ( $1 \mathrm{~mL}$ per well) and treated with different concentrations of casticin $(0,100,125,150,175$ and $200 \mathrm{nM}$ ). A $50 \mu \mathrm{L}$ of medium were separated on $8 \%$ sodium dodecyl sulfate (SDS)-polyacrylamide gel polymerized with $0.19 \%$ gelatin. After electrophoresis, the gels were washed with $\mathrm{ddH}_{2} \mathrm{O}$ and incubated in a renaturing buffer $\left(2.5 \%\right.$ Triton $\mathrm{X}-100$ in $\mathrm{ddH}_{2} \mathrm{O}, 3$ times, $\left.15 \mathrm{~min}\right)$. After renaturing, incubated gel in the developing buffer (50 mM. Tris- $\mathrm{HCl}, 150 \mathrm{mM} \cdot \mathrm{NaCl}, 10 \mathrm{mM} \cdot \mathrm{CaCl}_{2}, 1 \mu \mathrm{M} \cdot \mathrm{ZnCl}_{2}$, $0.02 \% \mathrm{NaN}_{3}, \mathrm{pH} 7.5$ ) for $24 \mathrm{~h}$ at $37^{\circ} \mathrm{C}$. After incubation, the gel was stained with $1.5 \%$ Coomassie R-250 and then destained with 10\% acetic acid in 30\% methanol. MMP-2 activity was visualized as clear bands against the blue-stained gelatin background [45].

\subsection{Nuclear Extract Preparation.}

The A375.S2 cells $\left(1 \times 10^{6}\right.$ cells/dish $)$ in $10 \mathrm{~cm}$ dish were treated with $200 \mathrm{nM}$ casticin for 0 , 6,9 , and $12 \mathrm{~h}$ and then cells were harvested. Cells from each time periods were fractionated into cytoplasmic and nuclear extracts using Nuclear Extraction Kit.

\subsection{Western Blotting Assay}

Samples were obtained from nuclear extract preparation or A375.S2 cells $\left(1 \times 10^{6}\right.$ cells/dish $)$ were kept in $10 \mathrm{~cm}$ dish and were treated with 0, 100, 125, 150, 175 and $200 \mathrm{nM}$ of casticin for $24 \mathrm{~h}$. Each total cell lysate was prepared in a lysis buffer ( $40 \mathrm{mM}$. Tris- $\mathrm{HCl}(\mathrm{pH} 7.4), 10 \mathrm{mM}$ EDTA, 120 $\mathrm{mM} \mathrm{NaCl}, 1 \mathrm{mM}$ dithiothreitol, $0.1 \%$ Nonide P-40) and quantitated by Bradford protein assay. Using BSA as standard. Equal amounts of protein $(30 \mu \mathrm{g})$ were separated on $10 \%$ sodium dodecyl sulphate (SDS)-polyacrylamide gel for electrophoresis and transferred onto a polyvinylidene fluoride (PVDF) membrane (Millipore, Temecula, CA, USA) by electro-blotting at $400 \mathrm{~mA}$ for $90 \mathrm{~min}$. After blocking with $5 \%$ nonfat skim milk, the membrane was probed with primary antibodies for NF- $k B$ p65, MMP-2, SOS1, Ras, p-ERK 1/2, p-MEK 1/2, p-c-jun, c-jun, p-EGFR, MMP-1, $\beta$-actin and specific secondary antibodies. The protein expression was detected by ECL solution (Millipore) as described previously [43-45].

\subsection{Electrophoretic Mobility shift Assay (EMSA)}

$1 \times 10^{7}$ cells in $10 \mathrm{~cm}$ dish were treated with casticin $(0$ and $200 \mathrm{nM})$ for 6,9 and $12 \mathrm{~h}$. Nuclear extracts were prepared using the NE-PER Nuclear and Cytoplasmic Extraction kit (Pierce, Rockford, IL, USA) as described previously [44]. Quantitated protein concentrations and $5^{\prime}$-Biotin-GATCCAGGGGACTTTCCCTAGC- $3^{\prime}$ corresponding to the consensus site of NF- $\mathrm{KB}$ was used as biotin end-labeled oligonucleotide sequences. A $5 \mu \mathrm{g}$ of nuclear extract proteins were used for EMSA with LightShift Chemiluminescent EMSA Kit based on the manufacturer's protocol. Biotin end-labeled duplex DNA was incubated with nuclear extracts or purified factor and were electrophoresed on a $6 \%$ polyacrylamide native gel. After electrophores, DNAs were transferred to a positive nylon membrane, UV cross-linked, probed with streptavidin-HRP conjugate and incubated with the substrates of the ECL kit as described previously [44].

\subsection{Statistical Analysis}

All data are presented as mean \pm S.D from at least three experiments. All statistics were calculated by Student's $t$ - test using Sigma plot software (software version 10.0, Systat Software Inc., San Jose, CA, USA) and a $p$ value of less than 0.05 was considered statistically significant. 


\section{Conclusions}

In summary, casticin decreased cell migration, adhension, invasion and expression of ECM-associated proteases in human melanoma A375.S2 cancer cells in vitro. Casticin suppressed the expressions of the MAPK and NF-KB signaling molecules involved in p-ERK 1/2, p-MEK 1/2, p-EGFR, and NF- $\mathrm{kB}$ signaling pathways for leading to the inhibition of MMP-2 and -1 in A375.S2 cancer cells. These findings strongly support the development of casticin as an anti-metastatic agent and an alternative therapeutic approach to combat human melanoma cell metastasis in the future.

Acknowledgments: This study was supported by the grant TSGH-C99-068 from Tri-Service General Hospital, Taipei, Taiwan. This study was supported by grant ASIA104-CMUH-04 from the Asia University, Taiwan

Author Contributions: Zih-Yun Wu, Jin-Cherng Lien, Yi-Ping Huang, Ching-Lung Liao, Jen-Jyh Lin, Ming-Jen Fan, Yang-Ching Ko, Yu-Ping Hsiao, Hsu-Feng Lu and Jing-Gung Chung were responsible for designing the study, conducting analyses, interpreting the output of analyses and preparing the manuscript for submission. Hsu-Feng Lu and Jing-Gung Chung interpreted data and revised the manuscript for intellectual content.

Conflicts of Interest: The authors declare that there are no conflicts of interest.

\section{References}

1. Bravo-Cordero, J.J.; Hodgson, L.; Condeelis, J. Directed cell invasion and migration during metastasis. Curr. Opin. Cell Biol. 2012, 24, 277-283. [CrossRef] [PubMed]

2. Siegel, R.; Ward, E.; Brawley, O.; Jemal, A. Cancer statistics, 2011: The impact of eliminating socioeconomic and racial disparities on premature cancer deaths. CA Cancer J. Clin. 2011, 61, 212-236. [CrossRef] [PubMed]

3. Webb, C.P.; Vande Woude, G.F. Genes that regulate metastasis and angiogenesis. J. Neurooncol. 2000, 50, 71-87. [CrossRef] [PubMed]

4. Khan, N.; Mukhtar, H. Cancer and metastasis: Prevention and treatment by green tea. Cancer Metastasis Rev. 2010, 29, 435-445. [CrossRef] [PubMed]

5. Sung, H.J.; Kim, Y.; Kang, H.; Sull, J.W.; Kim, Y.S.; Jang, S.W.; Ko, J. Inhibitory effect of Trolox on the migration and invasion of human lung and cervical cancer cells. Int. J. Mol. Med. 2012, 29, 245-251. [PubMed]

6. Tsai, J.P.; Hsiao, P.C.; Yang, S.F.; Hsieh, S.C.; Bau, D.T.; Ling, C.L.; Pai, C.L.; Hsieh, Y.H. Licochalcone A suppresses migration and invasion of human hepatocellular carcinoma cells through downregulation of MKK4/JNK via NF-kappaB mediated urokinase plasminogen activator expression. PLoS ONE 2014, 9, e86537. [CrossRef] [PubMed]

7. Tryggvason, K.; Hoyhtya, M.; Pyke, C. Type IV collagenases in invasive tumors. Breast Cancer Res. Treat. 1993, 24, 209-218. [CrossRef] [PubMed]

8. Koshikawa, N.; Giannelli, G.; Cirulli, V.; Miyazaki, K.; Quaranta, V. Role of cell surface metalloprotease MT1-MMP in epithelial cell migration over laminin-5. J. Cell Biol. 2000, 148, 615-624. [CrossRef] [PubMed]

9. Lochter, A.; Bissell, M.J. An odyssey from breast to bone: Multi-step control of mammary metastases and osteolysis by matrix metalloproteinases. APMIS 1999, 107, 128-136. [CrossRef] [PubMed]

10. Lai, W.C.; Zhou, M.; Shankavaram, U.; Peng, G.; Wahl, L.M. Differential regulation of lipopolysaccharide-induced monocyte matrix metalloproteinase (MMP)-1 and MMP-9 by p38 and extracellular signal-regulated kinase 1/2 mitogen-activated protein kinases. J. Immunol. 2003, 170, 6244-6249. [CrossRef] [PubMed]

11. Lynch, C.C.; Matrisian, L.M. Matrix metalloproteinases in tumor-host cell communication. Differentiation 2002, 70, 561-573. [CrossRef] [PubMed]

12. Gialeli, C.; Theocharis, A.D.; Karamanos, N.K. Roles of matrix metalloproteinases in cancer progression and their pharmacological targeting. FEBS J. 2011, 278, 16-27. [CrossRef] [PubMed]

13. Ko, W.G.; Kang, T.H.; Lee, S.J.; Kim, N.Y.; Kim, Y.C.; Sohn, D.H.; Lee, B.H. Polymethoxyflavonoids from Vitex rotundifolia inhibit proliferation by inducing apoptosis in human myeloid leukemia cells. Food Chem. Toxicol. 2000, 38, 861-865. [CrossRef]

14. Lee, C.; Lee, J.W.; Jin, Q.; Lee, H.J.; Lee, S.J.; Lee, D.; Lee, M.K.; Lee, C.K.; Hong, J.T.; Lee, M.K.; Hwang, B.Y. Anti-inflammatory constituents from the fruits of Vitex rotundifolia. Bioorg. Med. Chem. Lett. 2013, 23, 6010-6014. [CrossRef] [PubMed] 
15. Sohn, S.H.; Ko, E.; Oh, B.G.; Kim, S.H.; Kim, Y.; Shin, M.; Hong, M.; Bae, H. Inhibition effects of Vitex rotundifolia on inflammatory gene expression in A549 human epithelial cells. Ann. Allergy Asthma Immunol. 2009, 103, 152-159. [CrossRef]

16. Mainardi, T.; Kapoor, S.; Bielory, L. Complementary and alternative medicine: Herbs, phytochemicals and vitamins and their immunologic effects. J. Allergy Clin. Immunol. 2009, 123, 283-294. [CrossRef] [PubMed]

17. Ono, M.; Yamamoto, M.; Yanaka, T.; Ito, Y.; Nohara, T. Ten new labdane-type diterpenes from the fruit of Vitex rotundifolia. Chem. Pharm. Bull. 2001, 49, 82-86. [CrossRef] [PubMed]

18. Feng, X.; Zhou, Q.; Liu, C.; Tao, M.L. Drug screening study using glioma stem-like cells. Mol. Med. Rep. 2012, 6, 1117-1120. [CrossRef] [PubMed]

19. Yang, J.; Yang, Y.; Tian, L.; Sheng, X.F.; Liu, F.; Cao, J.G. Casticin-induced apoptosis involves death receptor 5 upregulation in hepatocellular carcinoma cells. World J. Gastroenterol. 2011, 17, 4298-4307. [CrossRef] [PubMed]

20. Zeng, X.; Fang, Z.; Wu, Y.; Zhang, H. [Chemical constituents of the fruits of Vitex trifolia L]. Zhongguo Zhong Yao Za Zhi 1996, 21, 167-168. [PubMed]

21. Lin, S.; Zhang, H.; Han, T.; Wu, J.Z.; Rahman, K.; Qin, L.P. In vivo effect of casticin on acute inflammation. Zhong Xi Yi Jie He Xue Bao 2007, 5, 573-576. [CrossRef] [PubMed]

22. Chen, D.; Cao, J.; Tian, L.; Liu, F.; Sheng, X. Induction of apoptosis by casticin in cervical cancer cells through reactive oxygen species-mediated mitochondrial signaling pathways. Oncol. Rep. 2011, 26, 1287-1294. [PubMed]

23. Kikuchi, H.; Yuan, B.; Yuhara, E.; Takagi, N.; Toyoda, H. Involvement of histone H3 phosphorylation through p38 MAPK pathway activation in casticin-induced cytocidal effects against the human promyelocytic cell line HL-60. Int. J. Oncol. 2013, 43, 2046-2056. [PubMed]

24. Zhou, Y.; Tian, L.; Long, L.; Quan, M.; Liu, F.; Cao, J. Casticin potentiates TRAIL-induced apoptosis of gastric cancer cells through endoplasmic reticulum stress. PLoS ONE 2013, 8, e58855. [CrossRef] [PubMed]

25. Liu, F.; Cao, X.; Liu, Z.; Guo, H.; Ren, K.; Quan, M.; Zhou, Y.; Xiang, H.; Cao, J. Casticin suppresses self-renewal and invasion of lung cancer stem-like cells from A549 cells through down-regulation of pAkt. Acta Biochim. Biophys. Sin. 2014, 46, 15-21. [CrossRef] [PubMed]

26. Choudhary, M.I.; Jalil, S.; Nawaz, S.A.; Khan, K.M.; Tareen, R.B. Antiinflammatory and lipoxygenase inhibitory compounds from Vitex agnus-castus. Phytother. Res. 2009, 23, 1336-1339. [CrossRef] [PubMed]

27. Mesaik, M.A.; Murad, S.; Khan, K.M.; Tareen, R.B.; Ahmed, A.; Choudhary, M.I. Isolation and immunomodulatory properties of a flavonoid, casticin from Vitex agnus-castus. Phytother. Res. 2009, 23, 1516-1520. [CrossRef] [PubMed]

28. Li, W.X.; Cui, C.B.; Cai, B.; Wang, H.Y.; Yao, X.S. Flavonoids from Vitex trifolia L. inhibit cell cycle progression at G2/M phase and induce apoptosis in mammalian cancer cells. J. Asian Nat. Prod. Res. 2005, 7, 615-626. [CrossRef] [PubMed]

29. Liou, C.J.; Len, W.B.; Wu, S.J.; Lin, C.F.; Wu, X.L.; Huang, W.C. Casticin inhibits COX-2 and iNOS expression via suppression of NF-kappaB and MAPK signaling in lipopolysaccharide-stimulated mouse macrophages. J. Ethnopharmacol. 2014, 158, 310-316. [CrossRef] [PubMed]

30. Lee, H.; Jung, K.H.; Lee, H.; Park, S.; Choi, W.; Bae, H. Casticin, an active compound isolated from Vitex Fructus, ameliorates the cigarette smoke-induced acute lung inflammatory response in a murine model. Int. Immunopharmacol. 2015, 28, 1097-1101. [CrossRef] [PubMed]

31. Koh, D.J.; Ahn, H.S.; Chung, H.S.; Lee, H.; Kim, Y.; Lee, J.Y.; Kim, D.G.; Hong, M.; Shin, M.; Bae, H. Inhibitory effects of casticin on migration of eosinophil and expression of chemokines and adhesion molecules in A549 lung epithelial cells via NF-kappaB inactivation. J. Ethnopharmacol. 2011, 136, 399-405. [CrossRef] [PubMed]

32. Weng, C.J.; Yen, G.C. The in vitro and in vivo experimental evidences disclose the chemopreventive effects of Ganoderma lucidum on cancer invasion and metastasis. Clin. Exp. Metastasis 2010, 27, 361-369. [CrossRef] [PubMed]

33. Kessenbrock, K.; Plaks, V.; Werb, Z. Matrix metalloproteinases: Regulators of the tumor microenvironment. Cell 2010, 141, 52-67. [CrossRef] [PubMed]

34. Babykutty, S.; Suboj, P.; Srinivas, P.; Nair, A.S.; Chandramohan, K.; Gopala, S. Insidious role of nitric oxide in migration/invasion of colon cancer cells by upregulating MMP-2/9 via activation of cGMP-PKG-ERK signaling pathways. Clin. Exp. Metastasis 2012, 29, 471-492. [CrossRef] [PubMed] 
35. Dung, T.D.; Feng, C.C.; Kuo, W.W.; Pai, P.; Chung, L.C.; Chang, S.H.; Hsu, H.H.; Tsai, F.J.; Lin, Y.M.; Huang, C.Y. Suppression of plasminogen activators and the MMP-2/-9 pathway by a Zanthoxylum avicennae extract to inhibit the HA22T human hepatocellular carcinoma cell migration and invasion effects in vitro and in vivo via phosphatase 2A activation. Biosci. Biotechnol. Biochem. 2013, 77, 1814-1821. [CrossRef] [PubMed]

36. Garg, P.; Sarma, D.; Jeppsson, S.; Patel, N.R.; Gewirtz, A.T.; Merlin, D.; Sitaraman, S.V. Matrix metalloproteinase-9 functions as a tumor suppressor in colitis-associated cancer. Cancer Res. 2010, 70, 792-801. [CrossRef] [PubMed]

37. Reddy, K.B.; Krueger, J.S.; Kondapaka, S.B.; Diglio, C.A. Mitogen-activated protein kinase (MAPK) regulates the expression of progelatinase B (MMP-9) in breast epithelial cells. Int. J. Cancer 1999, 82, 268-273. [CrossRef]

38. Liotta, L.A.; Tryggvason, K.; Garbisa, S.; Hart, I.; Foltz, C.M.; Shafie, S. Metastatic potential correlates with enzymatic degradation of basement membrane collagen. Nature 1980, 284, 67-68. [CrossRef] [PubMed]

39. Anand, M.; Van Meter, T.E.; Fillmore, H.L. Epidermal growth factor induces matrix metalloproteinase-1 (MMP-1) expression and invasion in glioma cell lines via the MAPK pathway. J. Neurooncol. 2011, 104, 679-687. [CrossRef] [PubMed]

40. Sweeney, C.; Li, L.; Shanmugam, R.; Bhat-Nakshatri, P.; Jayaprakasan, V.; Baldridge, L.A.; Gardner, T.; Smith, M.; Nakshatri, H.; Cheng, L. Nuclear factor-kappaB is constitutively activated in prostate cancer in vitro and is overexpressed in prostatic intraepithelial neoplasia and adenocarcinoma of the prostate. Clin. Cancer Res. 2004, 10, 5501-5507. [CrossRef] [PubMed]

41. Price, J.T.; Tiganis, T.; Agarwal, A.; Djakiew, D.; Thompson, E.W. Epidermal growth factor promotes MDA-MB-231 breast cancer cell migration through a phosphatidylinositol 3'-kinase and phospholipase C-dependent mechanism. Cancer Res. 1999, 59, 5475-5478. [PubMed]

42. Pasparakis, M.; Courtois, G.; Hafner, M.; Schmidt-Supprian, M.; Nenci, A.; Toksoy, A.; Krampert, M.; Goebeler, M.; Gillitzer, R.; Israel, A.; et al. TNF-mediated inflammatory skin disease in mice with epidermis-specific deletion of IKK2. Nature 2002, 417, 861-866. [CrossRef] [PubMed]

43. Chang, Y.-M.; Velmurugan, B.K.; Kuo, W.-W.; Chen, Y.-S.; Ho, T.-J.; Tsai, C.-T.; Ye, C.-X.; Tsai, C.-H.; Tsai, F.-J.; Huang, C.-Y. Inhibitory effect of alpinate Oxyphyllae fructus extracts on Ang II-induced cardiac pathological remodeling-related pathways in $\mathrm{H} 9 \mathrm{c} 2$ cardiomyoblast cells. Biomedicine 2013, 3, 148-152. [CrossRef]

44. Wu, S.H.; Hsiao, Y.T.; Kuo, C.L.; Yu, F.S.; Hsu, S.C.; Wu, P.P.; Chen, J.C.; Hsia, T.C.; Liu, H.C.; Hsu, W.H.; et al . Bufalin Inhibits NCI-H460 Human Lung Cancer Cell Metastasis In Vitro by Inhibiting MAPKs, MMPs, and NF-kappaB Pathways. Am. J. Chin. Med. 2015, 43, 1247-1264. [CrossRef] [PubMed]

45. Liao, C.L.; Lin, J.H.; Lien, J.C.; Hsu, S.C.; Chueh, F.S.; Yu, C.C.; Wu, P.P.; Huang, Y.P.; Lin, J.G.; Chung, J.G. The crude extract of Corni Fructus inhibits the migration and invasion of U-2 OS human osteosarcoma cells through the inhibition of matrix metalloproteinase-2/-9 by MAPK signaling. Environ. Toxicol. 2015, 30, 53-63. [CrossRef] [PubMed]

Sample Availability: Casticin are available from the Sigma-Aldrich Corp. (St. Louis, MO, USA).

(C) 2016 by the authors; licensee MDPI, Basel, Switzerland. This article is an open access article distributed under the terms and conditions of the Creative Commons by Attribution (CC-BY) license (http:/ / creativecommons.org/licenses/by/4.0/). 